\title{
Comparison of Chemical Composition and Antioxidant Capacity of Fruit, Flower and Bark of Viburnum opulus
}

\author{
Dominika Polka $^{1} \cdot$ Anna Podsędek ${ }^{1}$ (D) Maria Koziołkiewicz $^{1}$
}

Published online: 19 July 2019

(C) The Author(s) 2019

\begin{abstract}
In this work, the profiles of phenolics, fiber, pectins, sugars, organic acids and carotenoids, vitamin $\mathrm{C}$, ash, protein and fat contents, as well as antioxidant capacity were compared in fruits, flowers, and bark of Viburnum opulus (VO). Antioxidant capacity was evaluated against ABTS, hydroxyl, peroxyl and superoxide free radicals, and as a reducing power by using in vitro test. The results showed great quantitative differences in the composition of the VO morphological parts tested. Fruits contained the highest concentrations of fat, organic acids, sugars, soluble dietary fiber $(10.57 \pm 0.54 ; 7.34 \pm 0.06 ; 32.27 \pm 1.25 ; 6.82 \pm$ $0.38 \mathrm{~g} / 100 \mathrm{~g}$ DW, respectively) and carotenoids $(2.70 \pm 0.07 \mathrm{mg} / 100 \mathrm{~g} \mathrm{DW})$. Whereas, the bark exceeded the remaining parts of the VO in terms of antioxidant capacity, ash $(9.32 \pm 0.17 \mathrm{~g} / 100 \mathrm{~g} \mathrm{DW})$, total $(59.34 \pm 0.75 \mathrm{~g} / 100 \mathrm{~g} \mathrm{DW})$ and insoluble dietary fiber $(58.20 \pm 0.73 \mathrm{~g} / 100 \mathrm{~g} \mathrm{DW})$ contents as well as phenolic compounds $(3.98 \pm 0.04 \mathrm{~g} / 100 \mathrm{~g} \mathrm{DW})$. Among the phenolic compounds quantified in this study, chlorogenic acid and (+)-catechin had the highest concentrations (> $1 \mathrm{~g} / 100 \mathrm{~g} \mathrm{DW})$ in the flowers and bark, respectively.
\end{abstract}

Keywords Viburnum opulus $\cdot$ Fruit $\cdot$ Flower $\cdot$ Bark $\cdot$ Macronutrients $\cdot$ Antioxidants

$\begin{array}{ll}\text { Abbreviations } \\ \text { VO } & \text { Viburnum opulus } \\ \text { ABTS } & \text { ABTS }^{*+} \text { radical cation scavenging capacity } \\ \text { CE } & \text { (+)-catechin equivalents } \\ \text { CSP } & \text { Chelator soluble pectins } \\ \text { CYE } & \text { Cyanidin equivalents } \\ \text { DW } & \text { Dry weight } \\ \text { FRAP } & \text { Ferric reducing power } \\ \text { FW } & \text { Fresh weight } \\ \text { GAE } & \text { Gallic acid equivalents } \\ \text { HORS } & \text { Hydroxyl radical scavenging capacity } \\ \text { HSP } & \text { Hydroxide-soluble pectins } \\ \text { IDF } & \text { Insoluble dietary fiber } \\ \text { KL } & \text { Klason lignins }\end{array}$

Electronic supplementary material The online version of this article (https://doi.org/10.1007/s11130-019-00759-1) contains supplementary material, which is available to authorized users.

Anna Podsędek anna.podsedek@p.lodz.pl

1 Institute of Technical Biochemistry, Department of Biotechnology and Food Sciences, Lodz University of Technology, Stefanowskiego 4/10, 90-924 Łódź, Poland

$\begin{array}{ll}\text { NS } & \text { Neutral sugars } \\ \text { ORAC } & \text { Oxygen radical scavenging capacity } \\ \text { SDF } & \text { Soluble dietary fiber } \\ \text { SORS } & \text { Superoxide anion radical scavenging capacity } \\ \text { TE } & \text { Trolox equivalents } \\ \text { UA } & \text { Uronic acid } \\ \text { WSP } & \text { Water soluble pectins }\end{array}$

\section{Introduction}

Viburnum opulus L. (Adoxaceae), commonly known as European guelder, is also called as European cranberrybush, guelder rose, wild guelder rose, cherry-wood, rose elder, crampbark tree and snowball bush, and gilaburu in Turkey [1-3]. It is widespread in Europe, North and Central Asia, and North Africa [2, 4]. Viburnum opulus (VO) is a valuable decorative, medicinal and food plant. In Russia, Ukraine and among many Siberian nations the VO fruits, despite their astringent-bitter-sour taste, are used in traditional cuisine as a component of marmalades, jams, cordials and liqueurs, and "Kalinnikov" pies as well as herbal teas [5]. Also, in Scandinavia the fruits are popular when cooked into preserves while in Canada they may replace cranberries [3]. In the 
Central Anatolia region of Turkey juice from VO fruits is produced as a commercial product [6].

The VO fruits and fruit juice have been used to treat a wide range of illnesses, including bleeding, heart disease, high blood pressure, coughs and cold, neurosis and diabetes [3, 7-9]. In animal studies, extracts of VO fruits prevented male reproductive system against damages caused by taxanes and showed anti-endometriotic activity $[6,10]$. Moreover, in vitro studies demonstrated the antioxidant properties of VO fruit, branch, leaf and bark extracts [11-16]. Health benefits of $V$. opulus result from the presence of bioactive components in the plant, such as phenolic compounds, vitamin C, carotenoids, triterpenes, iridoids, essential oils, saponins and dietary fiber [5, 16-18]. As reported by several authors the levels of bioactive compounds vary between fruit genotypes and parts of plant $[1,18,19]$.

So far, most of the research have been carried out to characterize the chemical composition of VO fruit and fruit juice. However, there is no information or little is known about the chemical characteristic of other parts of the plant for which health-promoting effects have also been demonstrated. The aim of this study is to compare the biochemical components and antioxidant potential of poorly described flowers and bark with well known fruits of VO to recommend the use of the most valuable VO parts in pharmaceutics, cosmetics and/or functional foods.

\section{Materials and Methods}

The material and methods section is presented as supplementary material 1 .

\section{Results and Discussion}

\section{Comparison of Macronutrients of VO Fruits, Flowers and Bark}

To our best knowledge, there are no reports on the basic chemical composition of VO bark and flowers. However, the content of macronutrients in VO fruits was previously analyzed by other authors $[1,4,18-20]$. The concentrations of the major components of the different morphological parts of $\mathrm{VO}$ are given in Table 1 . The statistically significant differences $(p<$ 0.05 ) between $\mathrm{VO}$ fruits, bark and flowers in terms of protein, ash, organic acids, sugars, dietary fiber and pectin contents were observed. The fruit of VO was characterized by the significantly highest content of fat $(10.57 \mathrm{~g} / 100 \mathrm{~g} \mathrm{DW})$, total organic acids (7.34 g/100 g DW) and total sugars (32.27 g/ $100 \mathrm{~g} \mathrm{DW})$ as well as the lowest concentration of ash (2.96 g/ $100 \mathrm{~g} \mathrm{DW})$ and total fiber (38.44 g/100 g DW). Meanwhile, the flower of $\mathrm{VO}$ was the richest in protein and pectins $(9.72$
Table 1 The elementary chemical composition of dried flowers, bark and fruits of Viburnum opulus

\begin{tabular}{|c|c|c|c|}
\hline \multirow{2}{*}{$\begin{array}{l}\text { Factor } \\
\text { Ash }\end{array}$} & \multicolumn{3}{|c|}{$\mathrm{g} / 100 \mathrm{~g}$ dried weight (DW) } \\
\hline & $4.07 \pm 0.06^{\mathrm{b}}$ & $9.32 \pm 0.17^{\mathrm{c}}$ & $2.96 \pm 0.22^{\mathrm{a}}$ \\
\hline Protein & $9.72 \pm 0.53^{\mathrm{c}}$ & $3.26 \pm 0.10^{\mathrm{a}}$ & $5.40 \pm 0.16^{\mathrm{b}}$ \\
\hline Fat & $5.39 \pm 0.26^{\mathrm{a}}$ & $10.06 \pm 0.01^{\mathrm{b}}$ & $10.57 \pm 0.54^{\mathrm{b}}$ \\
\hline Organic acids total & $1.81 \pm 0.02^{\mathrm{a}}$ & $1.84 \pm 0.05^{\mathrm{a}}$ & $7.34 \pm 0.06^{\mathrm{b}}$ \\
\hline Oxalic acid & $0.54 \pm 0,02^{\mathrm{a}}$ & $0.85 \pm 0.01^{\mathrm{b}}$ & - \\
\hline Citric acid & - & - & $3.09 \pm 0.01$ \\
\hline Tartaric acid & $0.18 \pm 0.01^{\mathrm{a}}$ & - & $0.37 \pm 0.02^{\mathrm{b}}$ \\
\hline Malic acid & $0.61 \pm 0.03^{\mathrm{a}}$ & - & $3.13 \pm 0.02^{\mathrm{b}}$ \\
\hline Quinic acid & - & - & $0.75 \pm 0.04$ \\
\hline Succinic acid & $0.48 \pm 0.03^{\mathrm{a}}$ & $0.97 \pm 0.06^{\mathrm{b}}$ & - \\
\hline Fumaric acid & - & $0.02 \pm 0.00$ & - \\
\hline Sugars total & $11.92 \pm 0.41^{\mathrm{b}}$ & $1.52 \pm 0.10^{\mathrm{a}}$ & $32.27 \pm 1.25^{\mathrm{c}}$ \\
\hline Fructose & $4.57 \pm 0.01^{\mathrm{a}}$ & - & $10.72 \pm 0.09^{\mathrm{b}}$ \\
\hline Glucose & $2.01 \pm 0.06^{\mathrm{a}}$ & - & $15.29 \pm 0.74^{\mathrm{b}}$ \\
\hline Sucrose & $5.34 \pm 0.35^{\mathrm{b}}$ & $1.52 \pm 0.10^{\mathrm{a}}$ & $6.26 \pm 0.43^{\mathrm{c}}$ \\
\hline Fiber total & $45.39 \pm 2.07^{\mathrm{b}}$ & $59.34 \pm 0.75^{\mathrm{c}}$ & $38.44 \pm 0.41^{\mathrm{a}}$ \\
\hline SDF UA & $1.87 \pm 0.12^{\mathrm{b}}$ & $0.19 \pm 0.01^{\mathrm{a}}$ & $2.10 \pm 0.08^{\mathrm{c}}$ \\
\hline SDF NS & $1.06 \pm 0.05^{\mathrm{a}}$ & $0.95 \pm 0.05^{\mathrm{a}}$ & $4.72 \pm 0.30^{\mathrm{b}}$ \\
\hline SDF total & $2.93 \pm 0.16^{\mathrm{b}}$ & $1.13 \pm 0.06^{\mathrm{a}}$ & $6.82 \pm 0.38^{\mathrm{c}}$ \\
\hline IDF UA & $0.35 \pm 0.03^{\mathrm{a}}$ & $9.93 \pm 0.26^{\mathrm{c}}$ & $2.35 \pm 0.10^{\mathrm{b}}$ \\
\hline IDF NS & $12.61 \pm 0.21^{\mathrm{b}}$ & $22.60 \pm 1.11^{\mathrm{c}}$ & $9.72 \pm 0.16^{\mathrm{a}}$ \\
\hline IDF KL & $29.50 \pm 2.23^{\mathrm{c}}$ & $25.67 \pm 1.71^{\mathrm{b}}$ & $19.54 \pm 0.24^{\mathrm{a}}$ \\
\hline IDF total & $42.46 \pm 2.05^{\mathrm{b}}$ & $58.20 \pm 0.73^{\mathrm{c}}$ & $31.62 \pm 0.18^{\mathrm{a}}$ \\
\hline Pectin total & $8.58 \pm 0.29^{c}$ & $4.15 \pm 0.06^{\mathrm{a}}$ & $6.23 \pm 0.26^{\mathrm{b}}$ \\
\hline WSP & $1,96 \pm 0.15^{\mathrm{b}}$ & $0.63 \pm 0.08^{\mathrm{a}}$ & $4.17 \pm 0.28^{\mathrm{c}}$ \\
\hline CSP & $4.29 \pm 0.08^{\mathrm{c}}$ & $1.92 \pm 0.06^{\mathrm{b}}$ & $1.69 \pm 0.07^{\mathrm{a}}$ \\
\hline HSP & $2.33 \pm 0.16^{\mathrm{c}}$ & $1.60 \pm 0.14^{\mathrm{b}}$ & $0.37 \pm 0.04^{\mathrm{a}}$ \\
\hline Dry matter ${ }^{*}$ & $94.05 \pm 0.33^{\mathrm{c}}$ & $93.02 \pm 0.28^{\mathrm{b}}$ & $88.09 \pm 0.28^{\mathrm{a}}$ \\
\hline
\end{tabular}

Values are expressed as mean $\pm \mathrm{SD}(n=3)$; $^{*}$ expressed in $\mathrm{g} / 100 \mathrm{~g}$ of product; SDF - soluble dietary fiber, IDF - insoluble dietary fiber, UA uronic acid, NS - neutral sugars, KL -Klason lignins, WSP - water soluble pectins, CSP - chelator soluble pectins, HSP - hydroxidesoluble pectins; mean values within a row with different letters are significantly different at $p<0.05$

and $8.58 \mathrm{~g} / 100 \mathrm{~g} \mathrm{DW}$, respectively). Among three VO anatomical parts tested bark had the highest content of ash $(9.32 \mathrm{~g} / 100 \mathrm{~g} \mathrm{DW})$ and total fiber $(59.34 \mathrm{~g} / 100 \mathrm{~g} \mathrm{DW})$. In the fresh VO fruits grown in Turkey the ratio of protein to ash was 1.8 and it was consistent with the value calculated for the 
VO dried fruit tested in this work [20]. In addition, the VO fruits tested were comparable to other fruits in terms of ash and protein contents, but exceeded them in terms of fat and fiber contents [21]. Whereas, VO flowers were characterized by a similar content of protein to Roselle flowers [22]. On the other hand, the content of ash in VO flowers was 2-3 times lower than in the mentioned above flowers. Fereira et al. [23] obtained the larger amount of ash (14.6 g/100 g DW) in Quercus faginea bark in comparison to our result for VO bark.

The results obtained for the sugars analysis are shown in Table 1. Sucrose, glucose and fructose were found in fruits and flowers of VO while bark contained only sucrose. The total sugars content was the highest in VO fruits $(32.27 \mathrm{~g} /$ $100 \mathrm{~g} \mathrm{DW}$ ), followed by VO flowers (near three times lower) and bark with above twenty times lower content in comparison to fruit. Glucose was predominant sugar (44.8\% of total sugars) in VO fruits and sucrose (47.4\% of total sugars) dominated in VO flowers. Glucose was also found as dominant sugar in VO fruits by Perova et al. [5]. Previously, it has been reported that fresh VO fruits contain near 9 times more reducing sugars than sucrose [18]. However, the present results show that this ratio was about four in dried VO fruits, which may suggest quantitative changes of sugars during drying. Slatnar and co-workers [24] showed that drying methods had influence on monomer sugars/sucrose ratio in fig fruits which in fresh figs was 49.4 while in sun-drying fruits 88.2 and in oven-drying figs. 38.9.

Data in Table 1 have showed that organic acids profile and concentration depend on part of VO plant. The total acid quantified in the samples ranged from 1.81 to $7.34 \mathrm{~g} / 100 \mathrm{~g}$ DW. Malic and citric acids were the main organic acids present in fruits, and they accounted for $84.7 \%$ of the total content. It is in agreement with data provided by Perova et al. [5] but incompatible with other studies $[1,4,19]$ where malic and tartaric acids dominated. In contrast to the cited studies neither oxalic acid, fumaric nor succinic acid were detected in the fruits analyzed in our laboratory. The dominant organic acid in VO bark was succinic acid (52.7\% of total content) while in flowers it was malic acid (33.7\% of total content).

The content and composition of soluble (SDF) and insoluble (IDF) dietary fiber fractions varied with parts of VO plant tested (Table 1). The total dietary fiber (DF) content ranged from $38.44 \mathrm{~g} / 100 \mathrm{~g}$ DW in fruits to $59.34 \mathrm{~g} / 100 \mathrm{~g}$ DW in bark.
The value for VO fruit is higher than data obtained for different edible fruits with DF content from 8.83 in watermelon to $38.27 \mathrm{~g} / 100 \mathrm{~g}$ DW in cloudberry $[21,25]$. The content of DF in VO flowers exceeded its level in Roselle flowers by $34 \%$ [22]. In the present study, the morphological parts of VO contained $82.3,93.5$ and $98.1 \%$ IDF of the DF in fruits, flowers and bark, respectively. The advantage of IDF over SDF content was also found in other fruits [25]. IDF is the fraction of DF which influences on consistency and stool weight and consequently reducing the intestinal transit time [26]. In all analyzed parts of VO plant, the decreasing rank of contents of particular IDF fractions was as follows: IDF KL > IDF NS > IDF UA. The SDF in fruit and bark of VO was dominated by neutral sugars (NS) fraction, while in flowers by uronic acid (UA) fraction. The SDF after ingestion is fermented by bacterial flora from gut leading to the production of the short chain fatty acids acetate, propionate and butyrate with various beneficial health effects [27]. Part of the SDF are pectins which content is shown in Table 1. Their total amounts varied significantly from 4.15 to $8.58 \mathrm{~g} / 100 \mathrm{~g} \mathrm{DW}$ of VO bark and flowers, respectively. Flowers and bark were dominated by ionically cross-linked pectin as reflected by the CSP (chelator-soluble pectin) value. Pectin of VO fruits mainly consisted of water-soluble pectin (WSP) which contribution in the total content of pectin in fruit and bark was the lowest.

\section{Natural Antioxidants of VO Fruits, Flowers and Bark}

The contribution of plant-derived compounds to health improvement has been partly attributed to their antioxidant capacity. The natural plant antioxidants are mainly phenolic compounds, carotenoids, and vitamins $\mathrm{C}$ and $\mathrm{E}$. A study was therefore undertaken to determine these phytocompounds contents in VO commercial products tested (Table 2). The statistically significant differences $(p<0.05)$ between VO dried fruits, bark and flowers in terms of total phenolics, flavonoids and proanthocyanidins were observed. Carotenoid content was the highest in VO fruits and similar in bark and flowers. The commercially available VO bark was characterized by the highest level of total phenolics, flavonoids and proanthocyanidins as compared to other parts of plant. Contrary, in none of the tested VO parts was found Lascorbic acid. According to the literature, the concentration
Table 2 The content of antioxidants in dried flowers, bark and fruits of Viburnum opulus

\begin{tabular}{llll}
\hline Antioxidant & Flowers & Bark & \multicolumn{1}{l}{ Fruits } \\
\hline Carotenoids (mg $\beta$-carotene/100 g DW) & $1.12 \pm 0.06^{\mathrm{a}}$ & $1.13 \pm 0.03^{\mathrm{a}}$ & $2.70 \pm 0.07^{\mathrm{b}}$ \\
Phenolics total (g GAE/100 g DW) & $3.51 \pm 0.13^{\mathrm{a}}$ & $3.98 \pm 0.04^{\mathrm{c}}$ & $3.73 \pm 0.16^{\mathrm{b}}$ \\
Flavonoids (g CE/100 g DW) & $1.67 \pm 0.07^{\mathrm{a}}$ & $2.25 \pm 0.12^{\mathrm{c}}$ & $2.01 \pm 0.11^{\mathrm{b}}$ \\
Proanthocyanidins (g CYE/100 g DW) & $0.22 \pm 0.00^{\mathrm{a}}$ & $1.03 \pm 0.03^{\mathrm{c}}$ & $0.52 \pm 0.02^{\mathrm{b}}$ \\
\hline
\end{tabular}

Values are expressed as mean $\pm \mathrm{SD}(n=3)$. GAE - gallic acid equivalents, $\mathrm{CE}-(+)$-catechin equivalents, $\mathrm{CYE}-$ cyanidin equivalents; mean values within a row with different letters are significantly different at $p<0.05$ 
of ascorbic acid and carotenoids in fresh VO fruits was in the range $12.4-164.0 \mathrm{mg}$ and $1.4-2.8 \mathrm{mg}$ per $100 \mathrm{~g}$ fresh weight (FW) $[1,4,5,16,18]$. Comparing these data with our results we may conclude about the negative impact of drying on these antioxidants. Kamiloglu et al. [28] in the review of influence drying process on stability of natural antioxidants in fruits have concluded that hot-air/oven drying caused a decrease in the content of vitamin $\mathrm{C}$ in the range of 30-72\%, and carotenoids from 0 to $90 \%$. Degradation of vitamin $\mathrm{C}$ and carotenoids during drying could be attributed to their high sensitivity to oxidation, as well as the depletion of these compounds due to their utilization for protecting the oxidation of polyphenols during drying. Comparative data for dried VO fruits, bark and flowers are not available. In addition, we have not known the drying methods used to obtain the VO drought analyzed in this work.

The obtained results showed that the content of total phenolics in VO different morphological parts was in the range of 3.51-3.98 g/100 g DW and significantly exceeded the concentration of carotenoids. For comparison, the content of phenolics was estimated at $0.68-0.83 \mathrm{~g} / 100 \mathrm{~g} \mathrm{FW}$ of VO fruits grown in Czech Republic and 0.40-0.73 g/100 g FW of fruits from Russia [5, 16]. Total phenolics in the fresh fruits grown in Turkey or in Lithuania were determined at 0.62-0.99 and $0.75-1.46 \mathrm{~g} / 100 \mathrm{~g}$ FW, respectively [4, 18]. Total flavonoids in VO fruits found in the literature was between $0.20-0.49 \mathrm{~g}$ of rutin equivalents per $100 \mathrm{~g} \mathrm{FW}$ according to colorimetric assay [4, 16], and from 0.004 to $0.255 \mathrm{~g} / 100 \mathrm{~g} \mathrm{FW}$ according to HPLC method [5]. In our study, total flavonoids varied from 1.67 (flowers) to 2.25 (bark) g (+)-catechin equivalents/100 g DW. Flavonoids accounted for 47.6, 53.9 and $56.5 \%$ of total phenolics in VO flowers, fruits and bark, respectively. Published data indicate that flavonoids accounted for $27.3-37.4 \%$ of the total polyphenol content in fresh VO fruits [4]. Çam et al. [19] have showed that VO seeds are better source of total phenolics and flavonoids than fruit flesh which contained 3.5- and 6.8-fold less phenolics and flavonoids. According to Perova et al. [5] proanthocyanidin content in VO fruits range from 0.20 to $0.53 \mathrm{~g} / 100 \mathrm{~g} \mathrm{FW}$ and they accounted for $49.9-100.0 \%$ of total phenolics. In our study, total proanthocyanidins in VO commercial products tested varied from 0.22 (flowers) to $1.03 \mathrm{~g} / 100 \mathrm{~g} \mathrm{DW}$ (bark) and accounted for $6.3 \%$ in flowers, $13.9 \%$ in fruits and $25.9 \%$ in bark of total phenolics.

Data on the composition of individual phenolic compounds are very important because the structure of phenolics significantly affects their properties. In connection with the above, the ethanolic extracts of VO fruits, flowers and bark were analyzed for the content of individual phenolic compounds using UPLC system. The results of qualitative and quantitative phenolic composition in VO samples are summarized in Table 3. In our study, the different biological parts of VO were characterised by a large variation in the amount of individual phenolic compounds tested. The results showed that hydroxycinnamic acids dominated in the VO fruits and flowers (88.26 and $97.23 \%$ of total phenolics) while flavanols in VO bark ( $80.06 \%$ of total phenolics). Additionally, we have not found flavonols in VO bark. The authors of the only report
Table 3 Content (mg/100 g DW) of phenolic compounds in dried flowers, bark and fruits of Viburnum opulus

\begin{tabular}{llll}
\hline Compound & Flowers & Bark & Fruits \\
\hline Procyanidin B1 & $25.46 \pm 0.10^{\mathrm{b}}$ & $437.79 \pm 0.19^{\mathrm{c}}$ & $14.02 \pm 0.64^{\mathrm{a}}$ \\
(+)-Catechin & $46.87 \pm 0.11^{\mathrm{a}}$ & $1062.43 \pm 1.27^{\mathrm{b}}$ & - \\
Procyanidin B2 & - & $116.47 \pm 0.48$ & - \\
$(-)$-Epicatechin & - & $95.87 \pm 1.00$ & - \\
Total flavanols & $72.33 \pm 0.18^{\mathrm{c}}$ & $1712.55 \pm 2.23^{1712}$ & $14.02 \pm 0.64^{\mathrm{b}}$ \\
Neochlorogenic acid & $17.22 \pm 0.03^{\mathrm{b}}$ & $41.51 \pm 0.04^{\mathrm{c}}$ & $7.22 \pm 0.22^{\mathrm{a}}$ \\
Chlorogenic acid & $1535.42 \pm 5.53^{\mathrm{c}}$ & $352.49 \pm 0.33^{\mathrm{a}}$ & $752.59 \pm 2.07^{\mathrm{b}}$ \\
Cryptochlorogenic acid & $6.78 \pm 0.01 \mathrm{~b}$ & $18.44 \pm 0.30^{\mathrm{c}}$ & $3.51 \pm 0.01^{\mathrm{a}}$ \\
p-Coumaric acid & - & $14.17 \pm 0.25$ & - \\
Total hydroxycinnamic acid & $1559.42 \pm 5.56^{1559}$ & $426.61 \pm 0.33^{\mathrm{a}}$ & $763.32 \pm 2.07^{\mathrm{b}}$ \\
Rutin & $10.05 \pm 0.02^{\mathrm{b}}$ & - & $5.39 \pm 0.03^{\mathrm{a}}$ \\
Isorhamnetin & $58.84 \pm 0.10^{\mathrm{b}}$ & - & $0.71 \pm 0.01^{\mathrm{a}}$ \\
Isorhamnetin 3-O-rutinoside & - & - & $1.60 \pm 0.02$ \\
Isorhamnetin 3-O-glucoside & $47.06 \pm 0.08$ & - & - \\
Quercetin 3-O-glucoside & $19.18 \pm 0.04$ & - & - \\
Total flavonols & $135.13 \pm 0.23^{\mathrm{b}}$ & - & $7.70 \pm 0.02^{\mathrm{a}}$ \\
Sum of phenolic compounds & $1766.88 \pm 5.97^{1776}$ & $2139.16 \pm 2.36^{2139}$ & $784.94 \pm 1.52^{\mathrm{a}}$ \\
\hline
\end{tabular}

Values are expressed as mean $\pm \mathrm{SD}(n=3)$, mean values within a row with different letters are significantly different at $p<0.05$ 
Table 4 Antioxidant capacity of dried flowers, bark and fruits of Viburnum opulus

\begin{tabular}{lllll}
\hline Assay & Unit & Flowers & Bark & Fruits \\
\hline ABTS & $\mathrm{mM} \mathrm{TE} / 100 \mathrm{~g} \mathrm{DW}$ & $16.18 \pm 1.35^{\mathrm{a}}$ & $40.21 \pm 0.67^{\mathrm{c}}$ & $26.57 \pm 1.71^{\mathrm{b}}$ \\
HORS & $\mathrm{mM} \mathrm{TE} / 100 \mathrm{~g} \mathrm{DW}$ & $8.23 \pm 0.39^{\mathrm{b}}$ & $5.91 \pm 0.33^{\mathrm{a}}$ & $10.05 \pm 0.31^{\mathrm{c}}$ \\
ORAC & $\mathrm{mM} \mathrm{TE} / 100 \mathrm{~g} \mathrm{DW}$ & $61.82 \pm 2.04^{\mathrm{b}}$ & $108.17 \pm 3.38^{\mathrm{c}}$ & $10.93 \pm 0.39^{\mathrm{a}}$ \\
FRAP & $\mathrm{mM} \mathrm{TE} / 100 \mathrm{~g} \mathrm{DW}$ & $13.65 \pm 0.64^{\mathrm{a}}$ & $23.47 \pm 1.50^{\mathrm{c}}$ & $19.29 \pm 0.83^{\mathrm{b}}$ \\
SORS & $\mathrm{mM} \mathrm{CE} / 100 \mathrm{~g} \mathrm{DW}$ & $91.13 \pm 3.40^{\mathrm{a}}$ & $115.44 \pm 5.28^{\mathrm{b}}$ & $89.77 \pm 2.56^{\mathrm{a}}$ \\
\hline
\end{tabular}

Values are expressed as mean $\pm \mathrm{SD}(n=3), \mathrm{TE}$ - trolox equivalents, $\mathrm{CE}-(+)$-catechin equivalents, mean values within a row with different letters are significantly different at $p<0.05$ on the polyphenol composition of VO bark using one- and two-dimensional paper and thin-layer preparative chromatography have reported the presence of such acids as: caffeic, chlorogenic, $p$-hydroxybenzoic and gallic [12]. Although we have the standards of gallic, $p$-hydroxybenzoic and caffeic acids, these compounds have not been detected in dried VO bark. In the present study, a comparison of the retention time and UV-Vis absorption spectra to those of the reference compounds allowed us to determine four flavanols and four hydroxycinnamic acids in VO bark with (+)-catechin as dominated phenolic compounds (1062.43 mg/100 g DW) followed by procyanidin B1 (437.79 mg/100 g DW) and chlorogenic acid $(352.49 \mathrm{mg} / 100 \mathrm{~g} \mathrm{DW})$. We provide the first report on the flavanols composition in VO bark.

Regarding the most studied phenolic profile of VO fruit, hydroxybenzoic and hydroxycinnamic acids, catechins and procyanidins as well as flavonols and anthocyanins were identified by HPLC-MS-TOF and HPLC methods [1, 3, 5]. However, the results of quantitative analysis are controversial. According to Özrenk et al. [1] the most abundant components in fruits were (+)-catechin (28-35 mg/100 g FW) and gallic acid (11-12 mg/100 g FW) while chlorogenic acid concentration was 8-10 times lower than the $(+)$-catechin content. On the other hand, Velioglu et al. [3] indicated chlorogenic acid (204 mg/100 g FW) as the main component of VO fruits followed by (+)-catechin $(29 \mathrm{mg} / 100 \mathrm{~g} \mathrm{FW})$. In the present study, chlorogenic acid (752.59 mg/100 g DW) dominated in VO dried fruits tested. Additionally, we have found in VO fruits quercetin and isorhamnetin glycosides like other authors $[3,5]$. Unfortunately, in the present study, the anthocyanins have not been found in dried VO fruits although they were identified in fresh fruits $[4,5,18]$. Published data indicate that VO fruits contain the different cyanidin glycosides which level ranged between 10 and $31 \mathrm{mg} / 100 \mathrm{~g} \mathrm{FW}$ [5]. It can be assumed that the lack of anthocyanins in dried VO fruits may have resulted from the drying process of fruit. The hotair/oven drying of different fruits decreased the total anthocyanin content in the range of 42-92\% [28]. For example, airdrying at $62-64{ }^{\circ} \mathrm{C}$ for $24 \mathrm{~h}$ caused $26-61 \%$ decreases in cyanidin-3-rutinoside content in fig, while drying at $70{ }^{\circ} \mathrm{C}$ resulted in $97 \%$ loss of cyanidin-3-glucoside in red guava, whereas sour cherry dried at $50-70{ }^{\circ} \mathrm{C}$ contained $27-38 \%$ less cyanidin-3-glucoside compared to the fresh fruits.

There are no previous studies and references on the phenolics composition of the VO flowers. We report here the first UPLC profile of VO flowers. According to our data, flowers were more abundant in hydroxycinnamic acids, flavonols, and flavanols compared to fruits. The main phenolic compounds in flowers was chlorogenic acid (1535.42 mg/100 $\mathrm{g} \mathrm{DW})$ followed by isorhamnetin (58.84 mg/100 $\mathrm{g} \mathrm{DW})$, isorhamnetin 3-glucoside (47.06 mg/100 g DW), and (+)-catechin (46.87 mg/100 g DW).

\section{Antioxidant Capacity of VO Fruits, Flowers and Bark}

The use of plants rich in antioxidants can prevent or delay the development of non-communicable diseases through processes involving reactive oxygen species. In biological system, reactive oxygen species, such as superoxide, hydroxyl radicals, can damage the DNA and lead to the oxidation of cellular lipid and proteins [29]. Antioxidant properties of VO flowers, bark and fruits were estimated by five different methods, as scavenging potential toward stable, synthetic $\mathrm{ABTS}^{\circ+}$ radical cation (ABTS) and toward reactive oxygen species such as ${ }^{\circ} \mathrm{OH}$ radical (HORS), $\mathrm{O}_{2}{ }^{--}$superoxide anion radical (SORS), peroxyl radical (ORAC) and as the potential to reduce ferric to ferrous ion (FRAP). Trolox - a water-soluble analog of vitamin E, was used as an antioxidant standard to determine the Trolox equivalent (TE). Exceptionally, (+)-catechin was used as the antioxidant standard in the SORS assay to determine the catechin equivalent (CE). The higher TE and CE values, the greater the antioxidant potential. The results for antioxidant

Table 5 Pearson's correlation coefficients $(r)$ between total phenolics, flavonoids and procyanidins content and antioxidant capacity of Viburnum opulus commercial products

\begin{tabular}{llllll}
\hline & ABTS & FRAP & ORAC & HORS & SORS \\
\hline Total phenolics & 0.999 & 0.993 & 0.510 & -0.589 & 0.861 \\
Flavonoids & 0.984 & 1 & 0.389 & -0.474 & 0.784 \\
Proanthocyanidins & 0.998 & 0.973 & 0.603 & -0.676 & 0.912 \\
\hline
\end{tabular}


capacity of VO natural antioxidants, extractable by $70 \%$ ethanol, are presented in Table 4. Significant differences $(p<$ 0.05 ) were found among the analyzed parts of VO in the antioxidant capacity, except VO flowers and fruits in SORS assay. The TE values varied from 16.18 to $40.21 \mathrm{mM} / 100 \mathrm{~g}$ DW of product in ABTS assay, from 5.91 to $10.05 \mathrm{mM} / 100 \mathrm{~g}$ DW in HORS method, from 10.93 to $108.17 \mathrm{mM} / 100 \mathrm{~g}$ DW in ORAC assay, and in the range $13.65-23.47 \mathrm{mM} / 100 \mathrm{~g} \mathrm{DW}$ in FRAP method. Antioxidant potential of VO products in SORS assay as CE ranged between 89.77 and $115.44 \mathrm{mM} /$ $100 \mathrm{~g}$ DW of product. The antioxidant capacity of VO different parts investigated was in the following order in HORS, SORS and ORAC assays: bark $>$ flowers $>$ fruits and the order in ABTS and FRAP assays was bark $>$ fruits $>$ flowers. The values obtained clearly reflect that the VO bark components showed the greatest antioxidant capacity, regardless of the method used. The scavenging effect of VO fruit components on $\mathrm{ABTS}^{*+}$, $\mathrm{DPPH}^{\cdot}$ (2,2-diphenyl-1-picrylhydrazyl), ${ }^{\circ} \mathrm{OH}$, $\mathrm{O}_{2}{ }^{-}$and $\mathrm{NO}^{\circ}$ (nitric oxide) radicals are reported in the literature $[11,16,19]$. Rop et al. [16] noticed the cultivar variability in case of scavenging effect of VO fruits on different free radicals. The antioxidant capacity of $\mathrm{VO}$ fruits toward $\mathrm{O}_{2}{ }^{-}$ radical was lower than $\mathrm{VO}$ branch and leaf activities but higher than VO leaf activity in DPPH assay [11]. In contrast to fruits, the antioxidant capacity of VO bark was determined only by Andreeva et al. [12] using the method of cathode voltammetry. According to our knowledge, there is no data on the antioxidant properties of VO flowers. The TE values for VO flowers observed in the present study are about twice and three times higher than those obtained for Roselle flowers in ABTS, FRAP and ORAC assays, respectively [22]. Correlations between antioxidant activity assays with phenolic compounds tested by colorimetric assays (Table 2) are presented in Table 5. High correlations were found between total phenolics, flavonoids and proanthocyanidins with ABTS and FRAP assays $(r \geq 0.97)$. Correlation analysis also evidenced a positive relationship between the total phenolic, flavonoid and proanthocyanidin contents with SORS test $(r \geq$ 0.78). On the other hand, the Pearson's coefficients listed in Table 5 suggest week correlation between the phenolic compound contents and ORAC assay and negative correlation with HORS test.

\section{Conclusion}

In conclusion, this research has comprehensively investigated the chemical composition and antioxidant capacity of different parts (fruits, flowers and bark) of Viburnum opulus (VO) which are commercially available in Poland. This is the first detailed report on the phytochemicals and antioxidant properties of VO flowers as well as on the macronutrients in VO bark. The results demonstrated the differences in the basic chemical and bioactive compounds composition, and antioxidant properties of different morphological parts of VO. Bark constituents were the most active against free radicals, which was consistent with its highest phenolic compounds contents, especially proanthocyanidins and flavanol monomers. In addition, our results indicate that VO bark and flowers have high commercial potential due to their higher dietary fibre and phenolics contents, and lower sugars concentration in comparison to VO fruits. Taking into account numerous published data on the relationship between the biological activity, especially antioxidant properties, and the content of phenolic compounds for future studies, it is necessary to investigate the phenolic compound profile of VO bark and flowers using mass spectrometry method.

Acknowledgments The present research was performed under the financial support of the Polish National Science Centre (project nr 2016/23/B/ NZ9/03629).

\section{Compliance with Ethical Standards}

Conflict of Interest The authors declare no conflict of interest.

Human and Animal Participants This article does not contain any studies with human or animal subjects.

Open Access This article is distributed under the terms of the Creative Commons Attribution 4.0 International License (http:// creativecommons.org/licenses/by/4.0/), which permits unrestricted use, distribution, and reproduction in any medium, provided you give appropriate credit to the original author(s) and the source, provide a link to the Creative Commons license, and indicate if changes were made.

\section{References}

1. Özrenk K, Gündoğdu M, Keskin N, Kaya T (2011) Some physical and chemical characteristics of gilaburu (Viburnum opulus L.) fruits in Erzincan region. Iğdır Univ J Inst Sci Technol 1:9-14

2. Sagdic O, Ozturk I, Yapar N, Yetim H (2014) Diversity and probiotic potentials of lactic acid bacteria isolated from gilaburu, a traditional Turkish fermented European cranberry bush (Viburnum opulus L.) fruit drink. Food Res Int 64:537-545

3. Velioglu Y, Ekici L, Poyrazoglu E (2006) Phenolic composition of European cranberry bush (Viburnum opulus L.) berries and astringency removal of its commercial juice. Int J Food Sci Technol 41: 1011-1015

4. Ersoy N, Ercisli S, Gundogdu M (2017) Evaluation of European cranberry bush (Viburnum opulus L.) genotypes for agro-morphological, biochemical and bioactive characteristics in Turkey. Folia Hort 29:181-188

5. Perova I, Zhogova A, Cherkashin A, Éller K, Ramenskaya G, Samylina I (2014) Biologically active substances from European guelder berry fruits. Pharm Chem J 48:332-339

6. Sarıözkan S, Türk G, Eken A, Bayram L, Baldemir A, Doğan G (2017) Gilaburu (Viburnum opulus L.) fruit extract alleviates testis and sperm damages induced by taxane-based chemotherapeutics. Biomed Pharmacother 95:1284-1294 
7. Česonienė L, Daubaras R, Viškelis P, Šarkinas A (2012) Determination of the total phenolic and anthocyanin contents and antimicrobial activity of Viburnum opulus fruit juice. Plant Foods Hum Nutr 67:256-261

8. Erdem G, Kesik V, Honca T, Özcan A, Uğuz S, Akgül EÖ, Aykutlug Ö, Alp BF, Korkmazer N, Saldir M, Bayrak Z (2016) Antinephrolithiatic activity of Persea americana (avocado) and Viburnum opulus (guelder rose) against ethylene glycol-induced nephrolithiasis in rats. Afr J Tradit Complement Altern Med 13: $110-119$

9. Zayachkivska O, Gzhegotsky M, Terletska O, Lutsyk D, Yaschenko A, Dzhura O (2006) Influence of Viburnum opulus proanthocyanidins on stress-induced gastrointestinal mucosal damage. J Physiol Pharmacol 57:155-167

10. Saltan G, Süntar I, Ozbilgin S, Ilhan M, Demirel M, Oz B, Akkol E (2016) Viburnum opulus L.: a remedy for the treatment of endometriosis demonstrated by rat model of surgically-induced endometriosis. J Ethnopharmacol 193:450-455

11. Altun M, Çitoğlu G, Yilmaz B, Çoban T (2008) Antioxidant properties of Viburnum opulus and Viburnum lantana growing in Turkey. Int J Food Sci Nutr 59:175-180

12. Andreeva TI, Komarova EN, Yusubov MS, Korotkova EI (2004) Antioxidant activity of cranberry tree (Viburnum opulus L.) bark extract. Pharm Chem J 38:548-550

13. Česonienè L, Daubaras R, Viškelis P (2008) Evaluation of productivity and biochemical components in fruit of different Viburnum accessions. Biologija 54:93-96

14. Erdogan-Orhan I, Altun M, Sever-Yilmaz B, Saltan G (2011) Antiacetylcholinesterase and antioxidant assets of the major components (salicin, amentoflavone, and chlorogenic acid) and the extracts of Viburnum opulus and Viburnum lantana and their total phenol and flavonoid contents. J Med Food 14:434-440

15. Kraujalytė V, Venskutonis P, Pukalskas A, Česonienè L, Daubaras R (2013) Antioxidant properties and polyphenolic compositions of fruits from different European cranberry bush (Viburnum opulus L.) genotypes. Food Chem 141:3695-3702

16. Rop O, Reznicek V, Valsikova M, Jurikova T, Mlcek J, Kramarova D (2010) Antioxidant properties of European cranberry bush fruit (Viburnum opulus var. edule). Molecules 15:4467-4477. https:// doi.org/10.3390/molecules 15064467

17. Rychlińska I (2008) Sterols and triterpenes in Viburnum opulus L. leaves. Herba Pol 54:59-65

18. Česonienè L, Daubaras R, Venclovienè J, Viškelis P (2010) Biochemical and agrobiological diversity of Viburnum opulus genotypes. Open Life Sci 5:864-871

19. Çam M, Hisil Y, Kuscu A (2007) Organic acid, phenolic content, and antioxidant capacity of fruit flesh and seed of Viburnum opulus. Chem Nat Compd 43:460-461
20. Kalyoncu IH, Ersoy N, Elidemir AY, Karali ME (2013) Some physico-chemical characteristics and mineral contents of gilaburu (Viburnum opulus L.) fruits in Turkey. Int Scholarly Sci Res Innov $7: 424-426$

21. Garcia-Amezquita LE, Tejada-Ortigoza V, Heredia-Olea E, SernaSaldívar SO, Welti-Chanes J (2018) Differences in the dietary fiber content of fruits and their by-products quantified by conventional and integrated AOAC official methodologies. J Food Compos Anal 67:77-85

22. Sáyago-Ayerdi SG, Arranz S, Serrano J, Goñi I (2007) Dietary fiber content and associated antioxidant compounds in roselle flower (Hibiscus sabdariffa L.) beverage. J Agric Food Chem 55:78867890

23. Ferreira JP, Miranda I, SousaVB PH (2018) Chemical composition of barks from Quercus faginea trees and characterization of their lipophilic and polar extracts. PLoS One 13:e0197135. https://doi. org/10.1371/journal.pone.0197135

24. Slatnar A, Klancar U, Stampar F, Veberic R (2011) Effect of drying of figs (Ficus carica L.) on the contents of sugars, organic acids, and phenolic compounds. J Agric Food Chem 59:11696-11702

25. Pastell H, Putkonen T, Rita H (2019) Dietary fibre in legumes, seeds, vegetables, fruits and mushrooms: comparing traditional and semi-automated filtration techniques. J Food Compos Anal 75:1-7

26. Montagne L, Pluske JR, Hampson D (2003) A review of interactions between dietary fiber and the intestinal mucus, and their consequences on digestive health in young-ruminant animals. Anim Feed Sci Technol 108:95-117

27. Tuohy KM, Conterno L, Gasperotti M, Viola R (2012) Upregulating the human intestinal microbiome using whole plant foods, polyphenols, and/or fiber. J Agric Food Chem 60:87768782

28. Kamiloglu S, Toydemir G, Boyacioglu D, Beekwilder J, Hall RD, Capanoglu E (2016) A review on the effect of drying on antioxidant potential of fruits and vegetables. Crit Rev Food Sci Nutr 56:110 129

29. Xu DP, Li Y, Meng X, Zhou T, Zhou Y, Zheng J, Zhang J-J, Li HB (2017) Natural antioxidants in foods and medicinal plants: extraction, assessment and resources. Int J Mol Sci 18:96-127

Publisher's Note Springer Nature remains neutral with regard to jurisdictional claims in published maps and institutional affiliations. 